\title{
Characterization and Classification of Selected Rice Soils of Tropical Rainforest Region, Southeastern Nigeria
}

\author{
S. N. Obasi ${ }^{1}$, E. U. Onweremadu ${ }^{2}$, Egbuche C. T. ${ }^{3}$, U. P. Iwuanyanwu ${ }^{1}$ \\ ${ }^{1}$ Department of Agricultural Technology, Imo State Polytechnic, Umuagwo Imo State, Nigeria \\ ${ }^{2}$ Soil Science Department, Federal University of Technology, Owerri, Imo State Nigeria \\ ${ }^{3}$ Department of Forestry and Wildlife Technology, Federal University of Technology, Owerri, Imo State Nigeria
}

\author{
Email address: \\ nathanielobasi2000@yahoo.com (S. N. Obasi)
}

\section{To cite this article:}

S. N. Obasi, E. U. Onweremadu, Egbuche C. T., U. P. Iwuanyanwu. Characterization and Classification of Selected Rice Soils of Tropical Rainforest Region, Southeastern Nigeria. Agriculture, Forestry and Fisheries. Special Issue: Environment and Applied Science Management in a Changing Global Climate. Vol. 4, No. 3-1, 2015, pp. 46-50. doi: 10.11648/j.aff.s.2015040301.18

\begin{abstract}
The study carried out in Amachi Izzi, Abakaliki, tropical rainforest region, Southeastern Nigeria was aimed at characterizing and classifying the lowland rice soils of the area. Three pedons were sunk, at the region. Results showed that soils were strongly acidic $(\mathrm{pH}<5.0)$, profiles 1 and 3 had low organic matter while profile 2 was moderate. Total nitrogen was also low to medium while available $\mathrm{P}$ was medium. Sand exhibited low variation $(\mathrm{CV} \leq 15 \%)$ at Profile 2 while it indicated moderate variation $(\mathrm{CV}>15 \leq 35 \%)$ at Profile 1 and Profile 3 . Silt varied lowly $(\mathrm{CV} \leq 15 \%)$ at Profile 1 and moderately $(\mathrm{CV}>15 \leq 35 \%)$ at Profile 2 and Profile 3. Clay varied highly $(\mathrm{CV}>35 \%)$ in all pedons of Abakaliki lowland soils. Base saturation varied highly $(\mathrm{CV}>35 \%)$ at Profile 1 and Profile 2 and lowly $(\mathrm{CV} \leq 15 \%)$ at Profile 3 . Al saturation varied highly $(\mathrm{CV}>35 \%)$ in all pedons at Ebonyi north lowlands. Ochric epipedons were observed in pedons 1, 2 and 3 and diagnostic subsurface horizons were kandic. The temperature regime and percentage base saturation were considered at the subgroup level in the soil taxonomy. Pedons 1 and 2 were classified as Fluvaquentic Eutrudepts and Eutric Cambisol (FAO - WRB) while Pedon 3 was classified as Fluvaquentic Dystrudepts and Dystric Cambisol (FAO - WRB).
\end{abstract}

Keywords: Soil Classification, Rice Soils, Soil Variability and Southeastern Nigeria

\section{Introduction}

It is still challenging to meet the specific target of the new millennium development goals (MDGs) on food security and sustainability in Nigeria. At an assumed growth rate of $3.2 \%$, Nigeria's population was expected to have exceeded 160 million by the year 2011. This population density ranked among the highest in the sub-Saharan Africa [1]. The population however depends on crop agriculture to provide food and support their livelihood in an agro-ecology reputed to be sensitive and fragile [2]. In order to make adequate and strategic plan towards sustaining the food needs of the country's growing population, serious attention is required in the area of the country's productive potential for major crops that the agro-ecology supports. Rice among other cereal crops such as sorghum, millet, is expected to contribute substantially in reducing food insecurity in Nigeria [3].

Hydromorphic (phreatic) and wetland (fluxial) rice cultivation requires specific characteristics of the soils of the colluvial footslopes and the valley bottoms. Rice being a semi-aquatic plant, poor to moderately-well drained conditions are best suited for hydromorphic and wetland rice cultivation. Well-drained and excessively drained soils carry a drought risk. [4] Stated that coarse-textured soils generally are less productive than soils with a fine texture. This is due to the lower inherent fertility of the former, but also to their higher percolation rates, by which nutrients (including fertilizers) are easily leached beyond the root zone. The inherent fertility of sandy soils in general is very low. In such soils, the cation exchange capacity (CEC) depends largely on the organic matter. This serves as storage for plant nutrients, but it is a source of nutrients too, mainly of nitrogen. In clayey soils, the fertility is generally higher [5]. In the valley bottoms, however, the fertility of the soils is governed by the hydrology of the valley [6].

Although Ebonyi State has been described to have the potential for upland and lowland rice production [7]; [8], there is very limited information on the classification of rice soils of northern Ebonyi State. Therefore, the objective of 
this research was to characterize and classify the soils of Ebonyi State using the USDA Soils taxonomy and correlated with the World Reference Base (WRB) legend.

\section{Materials and Methods}

The study was conducted in Amachi-Izzi near Abakaliki, tropical rainforest region, Southeastern Nigeria which lies between latitudes $6^{\circ} 20^{\prime}$ and $6^{\circ} 30^{\prime} \mathrm{N}$ and longitudes $8^{\circ} 05^{\prime}$ ' and $8^{\circ} 40^{\prime}$ E. Parent material has been identified as a mixture of shale, Alluvium and sandstone within the tropical rainforest zone of the southeastern Nigeria. It experiences rainfall most of the months of the year and having highest intensities occurring between June-August. Mean annual rainfall is between 1800-2300 $\mathrm{mm}$.

\subsection{Field Work}

Lowland rice land use was considered in the experiment, three profile pits were sunk in the investigated lowland rice soils through which soils were characterized and classified.

\subsection{Laboratory Analyses}

Particle size distribution was determined by hydrometer method according the procedure of [9]. Bulk Density was measured by core method [10]. Soil $\mathrm{pH}$ was measured electrometrically in 1:2.5 soil/ water ratio [11]. Organic Carbon was determined using method described by [12]. Total nitrogen was determined using modified micro Kjeldahl method [13]. Total available phosphorus was determined using Bray II method [14]. Exchangeable cations were extracted with $0.1 \mathrm{M} \mathrm{BaCl} 2$ method [11] and analyzed with atomic absorption spectrometer. Exchangeable acidity was determined by the $\mathrm{KCl}$ extraction method and the extractant was titrated against $0.05 \mathrm{~N} \mathrm{NaOH}$. Effective cation exchangeable capacity (ECEC) was calculated as the summation of the exchangeable bases and $\mathrm{KCl}$ extractable $\mathrm{Al}$ and $\mathrm{H}$. The percentage base saturation (BS) was the summation of total exchangeable bases expressed as a percentage of ECEC.

\subsection{Data Analyses}

Soil data was subjected to Coefficient of variation (C.V.) ranked as follow; Low variation $(\leq 15 \%)$, Moderate variation $(>15 \leq 35 \%)$, High variation $(>35 \%)$ was used to estimate the degree of variability of soil properties [15].

\section{Results and Discussion}

The profiles were deep enough for rice cultivation and drainage indicated imperfectly drained due to high water table (Table 1). The color of the soils ranged from very pale brown (10YR 7/4) to yellow (10 YR 7/8) in Profile 1, Very pale brown (10 YR 8/3) to yellow (10 YR 8/6) in Profile 2 and Very pale brown in Profile 3 , all colors were tested under wet condition. The imperfectly drained condition may have induced this matrix color. Textural class is from silty loam (SiL) to clay loam (CL) in all pedons in this mapping unit. There were common and medium distinct to many coarse and distinct mottles at the $\mathrm{Btg}$ and $\mathrm{BCg}$ of Profile 1 respectively. At Profile 2 mottles ranged from few fine and faint to very coarse and distinct mottles. Also at Profile 3 mottles ranged from few fine and faint to common coarse and distinct. Soil structure indicated weak crumby and medium to moderate crumby and coarse at the Profile 1. At the Profile 2 and Profile 3 there were weak crumby and medium to strong blocky and very coarse structure.

Table 1. Soils Morphological and Physical Properties

\begin{tabular}{|c|c|c|c|c|c|c|c|c|c|c|}
\hline \multirow{2}{*}{ Horizon } & \multirow{2}{*}{ Depth (cm) } & \multirow{2}{*}{ Colour (moist) } & \multirow{2}{*}{ Mottles } & \multirow{2}{*}{ Text. Class } & \multirow{2}{*}{ Struct. } & \multicolumn{2}{|c|}{ Soil Texture } & \multirow[b]{2}{*}{ Clay } & \multirow{2}{*}{ BD } & \multirow{2}{*}{ Porosity } \\
\hline & & & & & & Sand & Silt & & & \\
\hline & Profile 1 & (P1) & & & & & & & & \\
\hline Ap & $0-13$ & 10YR7/4 & - & $\mathrm{SiL}$ & $1, \mathrm{cr}, \mathrm{m}$ & 428.0 & 505.6 & 66.4 & 1.31 & 50.0 \\
\hline $\mathrm{AB}$ & $13-34$ & $10 \mathrm{YR} 8 / 2$ & - & $\mathrm{SiL}$ & $1, \mathrm{cr}, \mathrm{m}$ & 368.0 & 485.6 & 126.4 & 1.33 & 49.8 \\
\hline Btg & $34-66$ & 10YR8/4 & $\mathrm{c}, 2, \mathrm{~d}$ & $\mathrm{~L}$ & $3, \mathrm{cr}, \mathrm{c}$ & 275.2 & 445.6 & 279.2 & 1.47 & 44.5 \\
\hline $\mathrm{BCg}$ & $66-98$ & 10YR7/8 & $\mathrm{m}, 3, \mathrm{~d}$ & CL & $2, \mathrm{cr}, \mathrm{c}$ & 287.9 & 385.7 & 326.4 & 1.57 & 40.8 \\
\hline \multirow[t]{2}{*}{ Mean } & & & & & & 339.0 & 455.6 & 199.6 & 1.42 & 46.4 \\
\hline & Profile 2 & (P2) & & & & & & & & \\
\hline Ap & $0-9$ & $10 Y R 8 / 3$ & $\mathrm{f}, 1, \mathrm{f}$ & $\mathrm{SiL}$ & $1, \mathrm{cr}, \mathrm{m}$ & 380.8 & 552.8 & 66.4 & 1.33 & 49.8 \\
\hline $\mathrm{AB}$ & $9-26$ & $10 Y R 7 / 4$ & - & $\mathrm{L}$ & $1, \mathrm{cr}, \mathrm{m}$ & 384.5 & 465.6 & 146.4 & 1.37 & 48.3 \\
\hline Btg & $26-54$ & 10YR8/4 & $\mathrm{f}, 2, \mathrm{~d}$ & $\mathrm{~L}$ & 2,bk,m & 348.0 & 405.6 & 246.4 & 1.45 & 45.3 \\
\hline $\mathrm{BCg}$ & 54-103 & 10YR8/6 & $\mathrm{v}, 3, \mathrm{~d}$ & $\mathrm{CL}$ & 3,bk,vc & 348.0 & 332.8 & 319.2 & 1.57 & 40.8 \\
\hline \multirow[t]{2}{*}{ Mean } & & & & & & 365.3 & 439.2 & 194.6 & 1.43 & 46.05 \\
\hline & Profile 3 & (P3) & & & & & & & & \\
\hline Ap & $0-15$ & $10 Y R 8 / 4$ & $\mathrm{f}, 1, \mathrm{f}$ & $\mathrm{SiL}$ & $1, \mathrm{cr}, \mathrm{m}$ & 346.1 & 535.6 & 116.4 & 1.33 & 49.8 \\
\hline $\mathrm{AB}$ & $15-35$ & $10 Y R 7 / 4$ & - & $\mathrm{L}$ & $1, \mathrm{cr}, \mathrm{m}$ & 485.2 & 345.6 & 169.2 & 1.36 & 48.6 \\
\hline Btg & $35-71$ & $10 \mathrm{YR} 8 / 2$ & $\mathrm{f}, 3, \mathrm{f}$ & $\mathrm{L}$ & $3, \mathrm{bk}, \mathrm{c}$ & 308.0 & 445.6 & 246.4 & 1.45 & 45.3 \\
\hline $\mathrm{BCg}$ & $71-112$ & 10YR8/4 & $\mathrm{c}, 3, \mathrm{~d}$ & $\mathrm{CL}$ & 3,bk,vc & 255.2 & 456.4 & 288.4 & 1.48 & 44.2 \\
\hline Mean & & & & & & 348.6 & 445.8 & 205.1 & 1.41 & 46.97 \\
\hline
\end{tabular}

Mottles: $1=$ fine, $2=$ medium, $3=$ coarse, $\mathrm{fe}=$ few, $\mathrm{f}=$ faint, $\mathrm{c}=$ common, $\mathrm{d}=$ distinct, $\mathrm{p}=$ prominent, $\mathrm{v}=$ very many, Texture: $\mathrm{L}=$ loam, SL Silty Loam, Structure: $1=$ weak, $2=$ moderate, $3=$ strong, $c r=$ crumb, $\mathrm{f}=$ fine, $\mathrm{m}=$ massive, $\mathrm{bk}=$ blocky, $\mathrm{vc}=$ very coarse, $\mathrm{m}=$ medium. 
Table 2. Ebonyi North Lowland Soils Chemical Properties

\begin{tabular}{|c|c|c|c|c|c|c|c|c|c|c|c|c|c|c|c|}
\hline \multirow{2}{*}{$\begin{array}{l}\text { Depth } \\
\text { (cm) }\end{array}$} & \multirow{2}{*}{$\begin{array}{l}\mathrm{pH} \\
\left(\mathrm{H}_{2} \mathbf{0}\right)\end{array}$} & \multirow{2}{*}{$\begin{array}{l}\text { OM } \\
\mathrm{g} / \mathrm{kg}\end{array}$} & \multirow{2}{*}{$\begin{array}{l}\text { TN } \\
\text { g/kg }\end{array}$} & \multirow{2}{*}{$\begin{array}{l}\text { Av.P } \\
\text { Mg/kg }\end{array}$} & \multirow{2}{*}{$\begin{array}{l}\text { Ca } \\
\leftarrow\end{array}$} & \multirow[t]{2}{*}{ Mg } & \multirow[t]{2}{*}{$\mathbf{K}$} & \multirow[t]{2}{*}{$\mathrm{Na}$} & \multirow{2}{*}{$\begin{array}{l}\text { TEB } \\
\mathrm{Cmol} / \mathrm{kg}\end{array}$} & \multirow[t]{2}{*}{$\underline{\text { Al }}$} & \multirow[t]{2}{*}{$\mathbf{H}$} & \multirow[t]{2}{*}{ TEA } & \multirow{2}{*}{$\stackrel{\text { ECEC }}{\longrightarrow}$} & \multirow{2}{*}{$\begin{array}{l}\text { B. Sat. } \\
(\%)\end{array}$} & \multirow{2}{*}{$\begin{array}{l}\text { Al Sat } \\
(\%)\end{array}$} \\
\hline & & & & & & & & & & & & & & & \\
\hline \multicolumn{16}{|l|}{ P 1.} \\
\hline $0-13$ & 3.77 & 29.6 & 1.5 & 7.39 & 1.33 & 0.80 & 0.03 & 0.05 & 2.21 & 1.43 & 0.98 & 2.41 & 4.62 & 47.83 & 30.95 \\
\hline $13-34$ & 4.66 & 22.7 & 1.1 & 13.9 & 1.34 & 0.40 & 0.07 & 0.07 & 1.88 & 0.80 & 1.00 & 1.80 & 3.68 & 51.08 & 21.74 \\
\hline $34-66$ & 4.88 & 13.1 & 0.7 & 7.25 & 1.28 & 0.73 & 0.04 & 0.07 & 2.08 & 1.32 & 0.96 & 2.28 & 4.36 & 47.71 & 30.27 \\
\hline $66-98$ & 4.36 & 13.1 & 0.6 & 8.34 & 8.24 & 1.02 & 0.09 & 0.05 & 9.40 & 0.01 & 0.40 & 0.41 & 9.81 & 95.82 & 0.10 \\
\hline Mean & 4.42 & 19.6 & 1.0 & 9.25 & 3.05 & 0.74 & 0.06 & 0.06 & 3.89 & 0.89 & 0.84 & 1.73 & 5.62 & 60.61 & 20.77 \\
\hline $\mathrm{CV}$ & 10.89 & 40.98 & 42.2 & 34.24 & 113.6 & 34.8 & 48.0 & 19.3 & 94.4 & 72.8 & 34.8 & 53.1 & 50.3 & 38.81 & 69.35 \\
\hline Rank & $*$ & $* * *$ & $* * *$ & $* *$ & $* * *$ & $* *$ & $* * *$ & $* *$ & $* * *$ & $* * *$ & $* *$ & $* * *$ & $* * *$ & $* * *$ & $* * *$ \\
\hline \multicolumn{16}{|l|}{ P 2.} \\
\hline $0-9$ & 4.88 & 39.2 & 2.0 & 7.32 & 1.20 & 0.34 & 0.02 & 0.05 & 1.61 & 0.72 & 0.72 & 1.44 & 3.05 & 52.79 & 23.60 \\
\hline $9-26$ & 3.55 & 17.2 & 0.9 & 12.67 & 1.23 & 0.38 & 0.09 & 0.02 & 1.72 & 0.52 & 1.56 & 2.08 & 3.80 & 45.26 & 13.68 \\
\hline $26-54$ & 4.85 & 15.8 & 0.8 & 12.59 & 1.48 & 0.45 & 0.09 & 0.07 & 2.09 & 2.00 & 1.12 & 3.12 & 5.21 & 40.11 & 38.39 \\
\hline $54-103$ & 5.55 & 11.0 & 0.6 & 16.77 & 4.00 & 0.73 & 0.08 & 0.34 & 5.15 & 0.01 & 0.16 & 0.17 & 5.32 & 96.80 & 0.18 \\
\hline Mean & 4.70 & 20.8 & 1.1 & 12.34 & 1.98 & 0.48 & 0.07 & 0.12 & 2.64 & 0.81 & 0.89 & 1.70 & 4.35 & 58.74 & 18.96 \\
\hline $\mathrm{CV}$ & 17.77 & 60.0 & 58.6 & 31.39 & 68.48 & 37.1 & 48.1 & 123. & 63.74 & 104. & 66.9 & 72.49 & 25.5 & 44.09 & 85.01 \\
\hline Rank & $* *$ & $* * *$ & $* * *$ & $* *$ & $* * *$ & $* * *$ & $* * *$ & $* * *$ & $* * *$ & $* * *$ & $* * *$ & $* * *$ & $* *$ & $* * *$ & $* * *$ \\
\hline \multicolumn{16}{|l|}{ Р 3.} \\
\hline $0-15$ & 4.52 & 36.5 & 1.8 & 9.91 & 1.12 & 0.60 & 0.06 & 0.07 & 1.85 & 1.16 & 1.20 & 2.36 & 4.21 & 43.94 & 27.55 \\
\hline $15-35$ & 4.67 & 24.1 & 1.2 & 8.26 & 1.44 & 0.54 & 0.05 & 0.08 & 2.11 & 0.76 & 1.12 & 1.88 & 3.99 & 52.88 & 19.05 \\
\hline $35-71$ & 3.84 & 0.70 & 0.1 & 7.55 & 1.44 & 0.64 & 0.05 & 0.10 & 2.23 & 1.60 & 0.40 & 2.00 & 4.23 & 52.71 & 37.82 \\
\hline $71-112$ & 4.67 & 12.4 & 0.4 & 6.99 & 1.51 & 0.72 & 0.09 & 0.21 & 2.53 & 0.80 & 1.67 & 2.47 & 5.00 & 50.60 & 16.00 \\
\hline Mean & 4.43 & 18.4 & 0.9 & 8.18 & 1.38 & 0.63 & 0.06 & 0.12 & 2.18 & 1.08 & 1.10 & 2.18 & 4.36 & 50.03 & 25.11 \\
\hline $\mathrm{CV}$ & 8.96 & 83.5 & 88.2 & 15.49 & 12.69 & 12.1 & 30.3 & 56.1 & 12.94 & 36.2 & 47.8 & 12.96 & 10.1 & 8.38 & 38.97 \\
\hline Rank & $*$ & $* * *$ & $* * *$ & $* *$ & * & $*$ & $* *$ & $* * *$ & $*$ & $* * *$ & $* * *$ & $* * *$ & $*$ & * & $* * *$ \\
\hline
\end{tabular}

$\mathrm{OM}=$ organic matter, $\mathrm{TN}=$ total nitrogen, Av.P = available phosphorus, $\mathrm{TEB}=$ total exchangeable bases, $\mathrm{TEA}=$ total exchangeable acidity, $\mathrm{ECEC}=$ effective cation exchange capacity, B. Sat $=$ base saturation, Al Sat. = aluminum saturation, CV=Coefficient of Variation, $*=$ Low variability, ${ }^{* *}=$ Moderate variability, $* * *=$ High Variability.

The sand content of profile 1 decreased down the profiles in all pedons with the means as follow; 339, 365.3 and $348.6 \mathrm{~g} / \mathrm{kg}$ in Profiles 1,2 and 3 respectively. Silt consistently decreased in Profile 1 and Profile 2; in their four pedogenic horizons respectively. There was an irregular silt distribution in Profile 3. Mean silt content was $456.6,439.2$ and $445.8 \mathrm{~g} / \mathrm{kg}$ in Profile 1, Profile 2 and Profile 3 respectively. Clay content increased down the profile in all pedons investigated at the Ebonyi North lowland mapping unit. In Profile 1, clay ranged as follow; $66.4,126.4,279.2$, and $326.4 \mathrm{~g} / \mathrm{kg}$ at the $\mathrm{Ap}, \mathrm{AB}, \mathrm{Btg}$ and $\mathrm{BCg}$ respectively. There was a similar trend in Profile 2; at their pedogenic horizons. The same trend continued in Profile 3 where clay ranged as; 116.4, 169.2, 246.4 and $288.4 \mathrm{~g} / \mathrm{kg}$ in four pedogenic horizons respectively. The mean clay content in Abakaliki lowland mapping unit was 199.6, 194.6 and $205.1 \mathrm{~g} / \mathrm{kg}$ in Profile 1, Profile 2 and Profile 3 respectively. The high silt content of soils of Abakaliki lowland soils could be attributed to low intensity of weathering of soils [16]. Also the consistent clay increase with depth was an indication of clay migration by lessivage to produce the process of illuviation. This has been observed by [17]. Sand exhibited low variation $(\mathrm{CV} \leq 15 \%)$ at Profile 2 while it indicated moderate variation $(\mathrm{CV}>15 \leq 35 \%)$ at Profile 1 and Profile 2. Silt varied lowly (CV $\leq 15 \%)$ at Profile 1 and moderately $(\mathrm{CV}>15 \leq 35 \%)$ at Profile 2 and Profile 3. Clay varied highly $(\mathrm{CV}>35 \%)$ in all pedons of Abakaliki lowland soils.

Silt/clay ration (SCR) in Ebonyi North lowland mapping unit indicated a decrease from top to bottom of three pedons in this location. SCRs were high $(1.04-7.62)$ suggesting that soils were of young parent materials as values exceeded 0.15 which has been reported [18] as benchmark for soils of old parent materials. SCR had high variation $(\mathrm{CV}>35 \%)$. Bulk density in Abakaliki lowland mapping unit also took an increasing trend from top to bottom of the pedons. Bulk density increased with depth in all the farms studied. This finding corroborates with those of [19] and [20]. Low bulk density reported in the soil may be a consequent of organic matter content of the soil. [21] Reported that low soil organic matter was responsible for increased bulk density in cultivated soils of Southeastern Nigeria. Within the profiles, possibility of migrating clay filling up the pore spaces in the horizons of illuviation may be account for the high bulk density values in the sub-surface horizons. Moreover, frequent cultivation of land made the soil loose and ultimately contributed for the low density in these layers. Results on bulk density were less than the critical limits for root restriction $(1.75-1.85 \mathrm{~g} / \mathrm{cm} 3)$ [22] indicating the potential of the soil to support rice production. The percentage total porosity of the soil ranged between 46 $50 \%$, with the surface horizons containing higher pore 
spaces. [23] Reported similar trend in selected paddy soils under long-term intensive fertilization. High pore spaces recorded in the surface horizons may be attributed to loosening of soil materials during puddling/cultivation of soil Bulk density and porosity varied lowly $(\mathrm{CV} \leq 15 \%)$ at Profiles 1 and 2 while they varied moderately $(\mathrm{CV}>15 \leq 35 \%)$ at profile 3 .

The Chemical properties of soils of Ebonyi North Lowland mapping unit as investigated in the study were shown in Table 2. The $\mathrm{pH}$ distribution indicated very acidic in all pedons of Abakaliki lowlands. Mean $\mathrm{pH}$ in water for profiles 1,2 and 3 were $4.42,4.70$ and 4.43 respectively. This $\mathrm{pH}$ range is strongly acidic $(<5)$ and could be due to Al saturation in soil solution [24]. The problem of strongly acid soils may also be caused by strong leaching from high rainfall, and mainly from oxidation of sulfidic material [25]. Soil $\mathrm{pH}$ exhibited low variation $(\mathrm{CV} \leq 15 \%)$ in all Abakaliki lowland pedons except Profile 2 where it moderately varied $(\mathrm{CV}>15 \leq 35 \%)$ $\mathrm{OM}$ and $\mathrm{TN}$ all decreased down the profile in all the pedons. Organic matter had means of 19.6, 20.8 and 18.4 $\mathrm{g} / \mathrm{kg}$ while mean total nitrogen were $1.0,1.1$ and $0.9 \mathrm{~g} / \mathrm{kg}$ all in Profiles 1, 2 and 3 respectively. Organic matter was low $(<20 \mathrm{~g} / \mathrm{kg})$ at Profiles 1 and 3 while moderate $(20-$ $42 \mathrm{~g} / \mathrm{kg})$ [25] at Profile 2. TN was moderate or medium $(0.5-1.5 \mathrm{~g} / \mathrm{kg})$ [25] in all pedons investigated at Abakaliki lowland soils. Organic matter and total nitrogen all had high variation $(\mathrm{CV}>35 \%)$ in all pedons at Abakaliki lowland profiles. The distribution of available phosphorus took an increasing trend in Profile 2, decreasing trend in Profile 3 and no particular trend in Profile 1. Mean available P was highest in Profile 2 (12.34 $\mathrm{mg} / \mathrm{kg})$, followed by Profile $1(9.25 \mathrm{mg} / \mathrm{kg})$ while the lowest occurred at Profile $3(8.18 \mathrm{mg} / \mathrm{kg})$. Available P was medium in Abakaliki lowland soils. [25] Reported the critical $\mathrm{P}$ values as $<5,5-15$ and $>15 \mathrm{mg} / \mathrm{kg}$ for low, medium and high respectively. Available $\mathrm{P}$ varied moderately $(\mathrm{CV}>15 \leq 35 \%)$ in all pedons at Abakaliki lowland soils.

Total exchangeable bases (TEB) in Abakaliki lowland mapping unit increased down the profile in all the pedons in this unit. The mean TEB distribution was highest in Profile $1(3.89 \mathrm{cmol} / \mathrm{kg})$ followed by Profile $2(2.64$ $\mathrm{cmol} / \mathrm{kg})$ whereas the lowest occurred at ALP3 (2.18 $\mathrm{cmol} / \mathrm{kg})$. TEB varied highly $(\mathrm{CV}>35 \%)$ at ALP1 and P2 while it exhibited low variation $(\mathrm{CV} \leq 15 \%)$ at Profile 3. Effective cation exchange capacity (ECEC) increased down the profiles in all the pedons. Mean ECEC were $5.62,4.35$ and $4.36 \mathrm{cmol} / \mathrm{kg}$. ECEC varied highly $(\mathrm{CV}>35 \%)$ at $\mathrm{P} 1$, moderately $(\mathrm{CV}>15 \leq 35 \%)$ at $\mathrm{P} 2$ and lowly $(\mathrm{CV} \leq 15 \%)$ at ALP3. Base saturation also increased down the profile in all pedons. Mean base saturation distribution was highest in P1 $(606.1 \mathrm{~g} / \mathrm{kg})$, followed by P2 $(587.4 \mathrm{~g} / \mathrm{kg})$ while the lowest occurred at P3 (500.3 $\mathrm{g} / \mathrm{kg})$. Base saturation varied highly $(\mathrm{CV}>35 \%)$ at $\mathrm{P} 1$ and $\mathrm{P} 2$ and lowly $(\mathrm{CV} \leq 15 \%)$ at $\mathrm{P} 3$. Mean $\mathrm{Al}$ saturation was highest at P3 $(251.1 \mathrm{~g} / \mathrm{kg})$ followed by P1 $(207.7 \mathrm{~g} / \mathrm{kg})$ and the lowest at P2 $(189.6 \mathrm{~g} / \mathrm{kg})$. Al saturation varied highly $(\mathrm{CV}>35 \%)$ in all pedons at Ebonyi north lowlands.

\section{Taxonomic Classification}

Mean annual soil temperatures were over $22^{\circ} \mathrm{C}$ and nearly constant within the study area [26]. Ochric epipedons were observed in pedons 1, 2 and 3 and diagnostic subsurface horizons were kandic. Isohyperthermic soil temperature regime placed pedons 1, 2 and 3 on the suborder Tropepts, organic matter contents and stratification qualified pedons as Fluvents, there was an irregular decrease in organic-carbon content (Holocene age) between a depth of $25 \mathrm{~cm}$ and either a depth of $125 \mathrm{~cm}$ below the mineral soil surface. The temperature regime and percentage base saturation were considered at the subgroup level in the soil taxonomy. A base saturation (by $\mathrm{NH}_{4} \mathrm{OAc}$ ) of more than 60 percent or more at a depth between 25 and $75 \mathrm{~cm}$ from the mineral soil surface at Pedons 1 and 2 while a base saturation (by NH4OAc) of less than 60 percent or more in one or more horizons at a depth between 25 and $75 \mathrm{~cm}$ from the mineral soil surface or directly above a root-limiting layer in Pedon 3. Therefore Pedons 1 and 2 were classified as Fluvaquentic Eutrudepts and Eutric Cambisol (FAO - WRB) while Pedon 3 was classified as Fluvaquentic Dystrudepts and Dystric Cambisol (FAO - WRB).

\section{Conclusion}

There was very high variability in the physical and chemical properties investigated. Agricultural intensification on the lowland rice soils requires the application of optimum rates of $\mathrm{N}$ and $\mathrm{P}$ fertilizers on soils derived from Shale and Recent Alluvium. The classification of the soils will also enhance the transfer of information about the soils within and between communities of soil users.

\section{References}

[1] IITA (1990) Annual Report 1989/90.International Institute of Tropical Agriculture, Ibadan Nigeria.

[2] IITA (1994) Annual Report 1993/94.International Institute of Tropical Agriculture, Ibadan Nigeria.

[3] Akpokodje, G; Lancon, F and Erenstein, O (2001) Nigerials rice economy: State of the Art. USAID Project report on the Nigerian rice economy in a competitive world:Constraints, opportunities and strategic choices. West Africa rice development Association (WARDA), Bouake, Cote d'Ivoire.

[4] Windmeijer, P.N., and W. Andriesse, (1993). Inland Valleys in West Africa: An Agro- Ecological Characterization of Rice Growing Environments. International Institute for Land Reclaimation and Imporvement.P.O. Box 45, 6700 AA Wageningen.The Netherlands.

[5] IRRI (1978).Soils and Rice. IRRI, Los Barios, The Philippines Kern, J. S., 1994. Spatial patterns of soil organic carbon in the contiguous United States, Soil Science Society of America Journal, 58: 439-55. 
[6] Moorman, F. R (1981). Representative of toposequence of soils in southern Nigeria and their pedology. In: Characterization of soils in relation to their classification and management for crop production D. J Greenland (ed). Clarendo Press Oxford. Pp10-29.

[7] Mbah, C.N., Anikwe, M.A.N. Onweremadu, E.U. and Mbagwu, J.S.C. (2007). Soil organic matter and carbohydrate contents of a Dystric Leptosol under organic waste management and their role in structural stability of soil aggregates. Int. J. Soil Sci. 2(4)L 268-277.

[8] Edeh, H.O., Eboh E.C., and Mbah, B.N., (2011). Analysis of Environmental Risk Factors Affecting Rice Farming in Ebonyi State, Southeastern Nigeria. World Journal of Agricultural Sci. 7(1): 100-103)

[9] Gee, G.W., and Or D. 2002. Particle size distribution: In Dane J.H., Topp G.C. (eds). Methods of soil analysis Part 4 Physical methods. Soil Sci. Soc. Am Book series No. 5 ASA and SSSA, Madison WI; 225-293.

[10] Grossman, R.B., Reinsch, T.G.(2002). Bulk density and linear extensibility, In: Dane, J.H., Topp, G.C. (eds). Methods of soil analysis, part 4 physical methods. Soil Sci. Soc. Am. Book Series No.5 ASA and SSSA, Madison WI 2002; 201-228

[11] Hendershot, H.W., H.L. Lalande and Duquette, 1993, Soil Reaction and Exchangeable Acidity in: Soil Sampling and Methods of Analysis. Cartar, M.R. (Ed.), Can. Soc. Soil Sci. Lewis Publishers, London, pp: 141-145.

[12] Nelson, D. W and L. E. Sommers. (1982). Total Carbon, Organic Carbon and Organic Matter in: Sparks, D. L. (Eds.), Methods of Soil Analysis. Part 3. SSSA Books Series No 5 SSSA Madison,

[13] Bremner, J.M. and Mulvany, C.S. 1982. Nitrogentotal. In: Methods of Soil Analysis, Part 2, Ed. A.L. P.G Miller and D.R Keeney (eds.) American Society of Agron. Madison WI, pp 593-624

[14] Olson, S. R. and L. E. Sommers. (1982). Phosphorus in: Methods of Soil Analysis. A. L. Page, R. HMiller and D. R. Keeney (eds). Maidson, W. I AmericalSciety of Agronomy: $1572 \mathrm{pp}$

[15] Wilding, L.P. (1985). Spatial variability, its documentation, accommodation and implication to soil surveys, pp. 166-194. In D.R. Nielsen and J. Bouma (eds.) Soil Spatial Variability: Produc, Wageningen, Netherlands.
[16] Moberg, J. P. and Esu I. E., (1991) Characteristics and composition of some savanna soils of Nigeria Geoderma 48:113-129.

[17] Essoka, A.W and Esu, I.E., (2001) Physical properties of inland valley soils of central Cross- River State of Nigeria. In Proceedings of the 27th annual conference of Soil Science Society of Nigeria 5- $9^{\text {th }}$ Nov. 2001 Calabar, Nigeria.

[18] Ayolagha, G.A (2001) Survey and Classification of Yenagoa meander belt soils in the Niger- Delta. In Proceedings of the 27th annual conference of Soil Science Society of Nigeria 59th Nov. 2001 Calabar, Nigeria.

[19] Onweremadu, E.U., Ndukwu, B.N., Opara, C.C and Onyia, V.N (2007).Characterization of wetland soils of Zarama, Bayelsa, State, Nigeria in relation to $\mathrm{Fe}$ and $\mathrm{Mn}$ distribution. Int. J. of Agriculture and Food Systems 1(1):80-86.

[20] Chikezie, A., Eswaran, H., Asawalam, D.O., and Ano, A.O. (2009). Characterization of the benchmark soils of contrasting parent materials in Abia State, South-eastern Nigeria. Global J. of Pure and Applied Sciences 16(1) 23-29.

[21] Akamigbo, F.O.R., (1999). Influence of land use on soil properties of the humid tropical agro-ecology of Southeastern Nigeria. Niger Agric J. 30: 59-76.

[22] Soil Survey Staff (1996), Soil quality information sheet; soil quality indicators Aggregate stability National Soil Survey Center in collaboration with NRCS, USDA and the national Soil Tilth.Laboratory, ARS, USDA.

[23] Khan, M.S.H, Abedin, M.M.J., Afrin A and Khosruzzaman, M. (2006). Physicochemical changes of paddy soils under long term intensive fertilization. Asian J. of plant Sciences 5(1) $105-110$.

[24] Soil Survey Laboratory Staff, (1992). Soil Survey Laboratory methods manual. USDA-SCS Soil Survey Investigations Report No. 42 Version 20. US Government Print Office Washington DC.

[25] Tabi, F.O., M. Omoko, A. Boukong, Ze.A.D. Mvondo, D. Bitondo and C. Fuh Che (2012), Evaluation of lowland rice (Oryza sativa) production system and management recommemdations for Logone and Chari flood plain- Republic of Cameroon. Agr Sc. Research J. Vol. 2(5): pp261 - 273.

[26] Lekwa, G., (1986). Soils of tidal marshes in the Kono-Imo River estuary, Rivers State, Nigeria. Niger J. Soil Sci. 6:47-56. 